\title{
The Banglar Ghuri as a Metaphor for Inclusive Sustainable Development
}

\author{
Werner Menski \\ Emeritus Professor, School of Law, SOAS, University of London
}

\section{INTRODUCTION}

Law cannot decree that kites shall fly high, ${ }^{1}$ or that a nation's future shall be golden. All of this requires complex efforts and is actually hard work. Following on from earlier articles assessing the progress of Bangladesh, particularly discussing the lawrelated difficulties of agreeing sustainable balances of competing visions and interests for national development, ${ }^{2}$ this article continues to use the image of the kite of law and life. In Bangladesh, significantly, this relates to the romantic, film-inspired image of a wish-kite, the iccher ghuri, as I learnt from Professor Taslima Monsoor and her late husband during a memorable trip in Bangladesh. The kite has become a useful metaphor to provide updated accounts on the always contested law-related precarities of a nation's developments. The iccher ghuri also supports a deeply interdisciplinary analysis of the enormous law-related challenges faced by Bangladesh, for law by itself would not make any kite fly and stay in the air safely.

The use of metaphors in the rapidly developing, highly complex field of comparative law is now widely recognised. ${ }^{3}$ What is also increasingly becoming clear in global legal scholarship is that 'all modern legal traditions are both mixed and mixing' (italics in the original). ${ }^{4}$ Hence, scholars trying to understand the ubiquitous liquidity, ${ }^{5}$ another prominent and quite pertinent metaphor, of a complex entity such as Bangladeshi law, have their work cut out to follow the rapidly progressing recent advances in developments of legal pluralism studies. ${ }^{6}$ Whether the focus of analysis falls on Italy,

1 A national law may of course ban kite flying, as notably happened in Pakistan, where kite flying was a popular game. See Werner Menski, 'Flying Kites in Pakistan: Turbulences in Theory and Practice' (2009-10) 1(1) Journal of Law and Social Research (Multan) 41-57.

2 Werner Menski, 'Flying Kites: Banglar Ghuri - Iccher Ghuri: Managing Family Laws and Gender Issues in Bangladesh' (2014) 25(2) Law Faculty Journal of Dhaka University 1- 20; Werner Menski, 'Bangladesh in 2015: Challenges of the Iccher Ghuri for Learning to Live Together' (2015) 1(1) Journal of Law and Politics, University of Asia-Pacific, Dhaka 9-32.

3 Seán Patrick Donlan and Jane Mair (eds.) Comparative Law. Mixes, Movements, and Metaphors (Routledge 2020).

4 Seán Patrick Donlan and Jane Mair, 'Of Mixes, Movements, and Metaphors' in Seán Patrick Donlan and Jane Mair (eds.) Comparative Law. Mixes, Movements, and Metaphors (Routledge 2020) 1, 3.

5 Werner Menski, 'The Liquidity of Law as a Challenge to Global Theorising' [2014] Jura Gentium XI: Pluralismo Giuridico. Annuale 19-42 [ISSN 1826-8269] [http://www.juragentium.org].

6 Werner Menski, 'On Kites and Ships: Climate Changes in Comparative Law and Judicial Navigation' in Seán Patrick Donlan and Jane Mair (eds.) Comparative Law. Mixes, Movements, and Metaphors (Routledge 2020) 67-86 comments also on Bangladesh; Roger Cotterrell, 'Still Afraid of Legal Pluralism? Encountering Santi Romano. Review Symposium: Law and Society Meets Jurisprudence' 
Turkey, or indeed Bangladesh, of major interest and importance is everywhere how any particular country manages its ongoing processes of identity formation, which nowhere, and certainly not in Bangladesh, is simply a finished product. ${ }^{7}$

Since this article is part of the celebrations of the Centenary of the Faculty of Law of the University of Dhaka in 2021, the present analysis is constructed in light of earlier historical developments affecting the territory now comprising the nation state of Bangladesh. Obviously, in 1921, when Dacca University was established, together with a Law School, there had already been an aborted effort to operate a divided Bengal between 1905 and 1911. However, in the volatile colonial environment of that time, there was as yet no clear vision of an independent nation state called Bangladesh. Indeed, the troubling division of Bengal along religious lines was abandoned within 6 years. Much later, even in the run-up to the brutal Partition of the subcontinent at midnight on 14/15 August $1947,{ }^{8}$ there was no political will on the part of the British colonisers as well as the majoritarian Muslim and Hindu politicians at that time to agree to an independent Muslim-dominated Bengali state in the Eastern part of South Asia. Hence, a period marked by subjugation of East Pakistan by a Punjabi-dominated West Pakistan between 1947 and 1971 that pushed for Urdu as a compulsory national language had to be suffered, until the complications and pressures became so strong and intolerably violent that a traumatic divorce became inevitable. However, the national independence of Bangladesh still had to be fought for on what became Bangladeshi territory in a blood-drenched war, with reverberations reaching well into the twenty-first century. Apart from periodic disasters imposed on the country by stormy winds, cyclones and the ubiquitous water, from numerous rivers and from the sea, ${ }^{9}$ man-made terror and multiple strenuous efforts to abuse every possible manifestation of law were to make a Golden Bangladesh a kind of 'distant mirage'. ${ }^{10}$

For, meanwhile the journey of independent Bangladesh since 1971 has given rise to enormous complications and turbulences for the kite of law and life. The moment they were left to themselves after having secured independence, the people of Bangladesh and their leaders realised that they were in fact a highly plural collection of people with various socio-cultural characteristics, many regional differences, and different religious beliefs within the new nation. Here we see at once that Professor Roger Cotterrell, in a recent analysis of concerns about legal pluralism, hits the nail on the

(2020) 45(2) Law \& Social Enquiry 539-558, 539 highlights lawyers' fears of legal insecurity and chaos.

7 Md Maidul Islam, 'Secularism in Bangladesh: an Unfinished Revolution' (2018) 38(1) South Asia Research 20-39.

8 Vazira Fazila-Yacoobali Zamindar, The Long Partition and the Making of Modern South Asia. Refugees, Boundaries, Histories (Columbia University Press 2007).

9 James J. Novak, Bangladesh. Reflections on the Water (second impression, The University Press Limited 2008).

10 This phrase was used by Antony Allott, The Limits of Law (Butterworths 1980) 216 with specific reference to the Uniform Civil Code project of India, a contested legal issue that has also caused unnecessary troubles in Bangladesh. Such a unification project is, not just in my view, a completely misguided remedy for achieving a Golden Bangladesh, since more respect for plurality, rather than enforced uniformity, is the need of the hour.

Page $\mid 2$ 
head when he observes that, "[t]oday, these issues of legal pluralism are never seen as purely juristic but always sociolegal in a broad sense - inseparable from social scientific perspectives'. ${ }^{11}$

As a socio-legal scholar from the start, and someone who never endorsed state-centric legalism on its own as a viable tool for holistic development, I have been privileged to accompany this potentially empowering, yet difficult journey since 1980 . I learnt a lot in and through this process about how easily various legal powers may become abused by specific stakeholders. My first publication on Bangladesh focused on Hindu law and religious minorities, ${ }^{12}$ but very soon I delved deeper into the intricacies of Bangladeshi constitutional arrangements and their complex relationships with developmental trajectories.

As a farmer's son, I was delighted to encounter a well-known Bangla saying on the importance of making the best butter out of milk. Bangladesh, however, not only suffers irritations in the processes of making butter but has experienced massive stealing and misappropriation of precious public and private resources, to an extent that impunity, corruption, and lack of transparency have become prominent concerns in most analyses of legal developments in Bangladesh. This has multiple negative impacts on empowerment. ${ }^{13}$ Deliberate infringements of the country's welfare and the people's best interests, and thus violations of public interest, remain unfortunately a major fact of postcolonial Bangladeshi legal and political life. The judiciary, which should ideally maintain whatever the principles of 'rule of law' are deemed to mean, have for many reasons not been as activist as one might hope and argue for. ${ }^{14}$ Sadly, these complications have become so convoluted that presently there seems to be no agreement about whom to blame, with completely contradictory accusations flying in all directions and dominating the various, now globalised and multilingual, media spaces that all kinds of 'activists' may - and vigorously do - use to critique law-related developments in Bangladesh. As editor of South Asia Research, I see much questionable writing coming from Bangladeshi authors who seem to have been seeking refuge abroad. Frequently in aggressive language, this seeks to influence developments in Bangladesh by some kind of remote control, demanding change without offering constructive advice on how to balance competing expectations. This disproportionate external intervention is somewhat dangerous because we hear comparatively little about the voices and actual concerns of people living in Bangladesh itself, who are often simply struggling to survive and thus have no time for internet politics and lawrelated discourses. They may also simply not be connected to these new media, ${ }^{15}$

11 Roger Cotterrell, 'Still Afraid of Legal Pluralism? Encountering Santi Romano. Review Symposium: Law and Society Meets Jurisprudence' (2020) 45(2) Law \& Social Enquiry 539, 553.

12 Werner Menski and Tahmina Rahman, 'Hindus and the Law in Bangladesh' (1988) 8(2) South Asia Research 111-131.

13 Sumaiya Khair, Legal Empowerment for the Poor and the Disadvantaged: Strategies, Achievements and Challenges. Experiences from Bangladesh (Author 2008) 33-34.

14 Ridwanul Hoque, Judicial Activism in Bangladesh. A Golden Mean Approach (Cambridge Scholars Publishing 2011).

15 Mohammad Sahid Ullah, 'Empowerment, Asymmetrical Power Relations and Impacts of Information Technology in Rural Bangladesh’ (2017) 37(3) South Asia Research 315-334. 
indicating further asymmetries of power which need to be openly acknowledged. It may be safer to focus on business development issues in this field, ${ }^{16}$ but there can be no doubt that this specific development discourse does not cover the entire law-related wider context.

The legal and political history of now postcolonial Bangladesh is therefore, it may be argued, a tragic case study of malfunctioning. It depicts a troubled trajectory, not once but repeatedly, of how authoritarian state structures, even after being overthrown in some form, have a habit of coming back in revised forms of excessive authoritarianism and defective forms of rule of law, despite the formal framework of a democratic structure. ${ }^{17}$

Presently, it remains a huge challenge for different aggressively competing stakeholders to work together constructively to promote the sustainable development of Bangladesh, indeed a massive, multi-dimensional challenge. Presently, there are worrying signs that the country's encouraging economic performance, with its partly empowering effects also for women, ${ }^{18}$ is now endangered by COVID-induced harm, which has hit garment exports, in particular.

Despite such huge challenges, this article offers a hopeful vision for a safe national journey. Yet let there be no doubt: This will require that, advised and led by the country's law-related intellectuals and professionals, all the various diverse people of Bangladesh have to learn to live and work together as members of a huge, internally plural nation. In this context, although by itself this is not enough, plurality-conscious legal education is set to become a key component to equip the next generation of citizens and their leaders at all levels with appropriate tools. Bangladesh is not some small city state or a kind of Switzerland. As a demographically large country, which is often dismissed as unimportant, it is both physically and in terms of governmentality much closer in its characteristics to India than many stakeholders are willing to accept. Yet Bangladesh - its people, but especially its lawyers and politicians - ought to learn lessons from wherever they may be found to identify an appropriate, sustainable path for the future, given that law is everywhere culture-specific. ${ }^{19}$ The article proceeds to first discuss the Banglar Ghuri image and its contested journey in light of multiple failures of responsible governance. It then argues that the synergies of private and public interest, inspired by the country's foundational vision, ought to energise the kite journey to promote a sustainable future even in post-COVID Bangladesh.

\section{THE BANGLAR GHURI AS A METAPHOR FOR HOPE AND GOOD GOVERNANCE}

16 Ahmed Tareq Rashid and Ahmed Khaled Rashid, 'Rural ICT Business in Bangladesh: A Credible Development Agent?' (2020) 40(1) South Asia Research 58-74.

17 Sonia Z. Khan, The Politics and Law of Democratic Transition: Caretaker Government in Bangladesh (Routledge 2018).

18 Mohammad Rafiqul Islam, 'Economic Growth Rates and Exports of Bangladesh: The Bengal Tiger? (2019) 39(3) South Asia Research 285-303.

19 Werner Menski, Comparative Law in a Global Context. The Legal Systems of Asia and Africa (2nd edn, Cambridge University Press 2006) 26-37.

Page $\mid 4$ 
As individual scholars, and also as law teachers, we can only hope to be effective, often in quite limited ways. People who read our work and also our students are not a tabula rasa, but already have their own views and preferences, which may be deeply entrenched. In the polarised environment of Bangladesh, whether someone supports the Awami League (AL) or the Bangladesh Nationalist Party (BNP) far too often seems to be all that counts. The challenge of teaching South Asian laws at SOAS in the University of London between 1980 and 2014, including Bangladeshi law, impressed on me that being able to listen to others and their concerns is a key skill. This can indeed be learnt 'on the job', whether as a teacher or a student, and at any time. Yet sadly, one constantly encounters much myopic prejudice, huge half-baked knowledge and many evidently misguided opinions. To assess what is right or wrong is of course a fundamental human predicament in any situation. But how does one counter blind prejudice and unwillingness to appreciate the perspective of 'the other' in so many difficult situations? For socio-legal scholars this predicament becomes akin to steering a kite safely through turbulent winds. Balancing and nimble navigation are key skills required also in conducting intensive seminars which challenge students to think, express their thoughts, and listen to others. In that complex learning and balancing process, either by practising those skills 10,000 times, or by silent osmosis over time, one turns into a pluri-legal scholar; at least that has been my experience. Looking back, I am happy to have nurtured many young skilled professionals, including numerous Bangladeshis, who are now active in many fields of life and work all over the globe.

If all legal orders are both mixed and mixing, ${ }^{20}$ there is no other way if one wants to keep law and life in productive synergy or harmony, while continuing to face the challenges of never-ending competing claims and expectations of the multiple roles that all humans play. There is then of course also never-ending scope for social and other normativities to conflict. ${ }^{21}$ Consequently, conflict management, another core skill closely connected to kite flying, and a key skill for lawyers, too, takes centre stage in legal education, in our thought processes, and in everything one may or may not do. Yet, how should one react if any 'other' self-righteously insists on pursuing conflict, rather than trying to find an agreeable solution and/or searching for plurality-conscious compromise of any issue that may arise?

To take a simple example often encountered as a teacher of South Asian laws, how could one uncritically accept the common claims of highly trained doctrinal lawyers that South Asian laws are simply inferior manifestations of English common law, rather than hybrid constructs arising from South Asian colonial legal history? ${ }^{22}$ Such conflicting perceptions, which also downplay the important position of South Asia's various personal law systems, seem to become more acrimonious when religion and

20 Seán Patrick Donlan and Jane Mair, 'Of Mixes, Movements, and Metaphors' in Seán Patrick Donlan and Jane Mair (eds.) Comparative Law. Mixes, Movements, and Metaphors (Routledge 2020) 1, 3.

21 Kyriaki Topidi (ed.) Normative Pluralism and Human Rights. Social Normativities in Conflict (Routledge 2018).

22 For a sophisticated account of how this worked out for Bangladesh, see Naim Ahmed, Public Interest Litigation. Constitutional Issues and Remedies (Bangladesh Legal Aid and Services Trust [BLAST] 1999) 20. 
law are the subject, often specifically when Islam is involved. ${ }^{23}$ That important recent writing has clarified such contested boundaries between law, culture and religion, ${ }^{24}$ and also between supposedly liberal modernity and allegedly traditional Islam, ${ }^{25}$ has apparently bypassed many Bangladeshis, including lawyers and lawyer-politicians who should know better. Instead, there is a depressing set of literature that reflects how such conflicts over law and religion have sparked globally unnoticed 9/11 moments for Bangladesh, constantly stirring up further aggressive confrontations, ${ }^{26}$ even risking at times a crashing of the wish kite of Bangladesh. Evidence of youth protests further complicates the turbulences experienced in recent times. ${ }^{27}$

Against this, we find the liberating thought that clearly also in terms of Qur' an and Sunna, a good Muslim is of necessity a pluralist. ${ }^{28}$ This is a perspective which empowers individual Muslims to find their own path, but it has been overlaid by various global and local attempts, some of them explicitly gendered, to dictate to believers how to live their lives. That these anti-pluralist attempts of enforcing an artificial uniformity of Islamic law for the sake of Political Islam do not reflect lived realities has long been known, also among lawyers who specialise in matters of Islamic law, ${ }^{29}$ and who are aware that deciding on the right path is everywhere a matter of conscience, conflicts and tensions. ${ }^{30}$ Examined through a global, comparative law lens, law is everywhere culture-specific, and thus manifests as diversified and highly mixed glocalisation, rather than simply uniformised globalisation. ${ }^{31}$ That this is now also recognised by development specialists, ${ }^{32}$ given the huge input of development activism in Bangladesh, bears importance also for legal education in Bangladesh.

Teaching about law as an interdisciplinary field of expertise is not just a matter of theory and courses on jurisprudence, however. I always told my students that a good theory must work in real life, otherwise it is simply ideology, which may be harmful for basic rights protection at grassroots level. From that perspective, too, there is no

23 Richard L Benkin (ed.) What Is Moderate Islam? (Lexington Books 2017) covers conflicts in Pakistan and in Bangladesh.

24 Shahab Ahmed, What is Islam? The Importance of Being Islamic (Princeton University Press 2016), emphasing the constant interaction of text, pre-text and context.

25 Arif A. Jamal, Islam, Law and the Modern State. (Re)Imagining Liberal Theory in Muslim Contexts (Routledge 2018), arguing that there is no necessarily irreconcilable conflict between liberal theory and Islam.

26 Mubashar Hasan, 'Democracy and Political Islam in Bangladesh' (2011) 31(2) South Asia Research 97-117; Md Maidul Islam, 'Secularism in Bangladesh: an Unfinished Revolution' (2018) 38(1) South Asia Research 20-39.

27 Anupam Debasish Roy, 'Shahbag Stolen? Third Force Dynamics and Electoral Politics in Bangladesh' (2018) 38(3S) South Asia Research 1S-25S.

28 Werner Menski, Comparative Law in a Global Context. The Legal Systems of Asia and Africa (2nd edn, Cambridge University Press 2006) 281.

29 David Pearl and Werner Menski, Muslim Family Law (3rd edn, Sweet \& Maxwell 1998).

30 The most instructive text on this remains, in my view, the brilliant and concise set of early lectures by Noel J. Coulson, Conflicts and Tensions in Islamic Jurisprudence (University of Chicago Press 1969).

31 William Twining, Globalisation \& Legal Theory (Butterworths 2000).

32 Brian Z. Tamanaha, Caroline Sage and Michael Woolcock (eds.) Legal Pluralism and Development. Scholars and Practitioners in Dialogue (Cambridge University Press 2012).

Page | 6 
reason to be scared about discussing legal pluralism. ${ }^{33}$ Whether in terms of social normativities, economic status, or regarding politics and law, plurality is manifestly everywhere part of life. This was also recognised quite some time ago by John Rawls, who proceeded to construct his famous phrase of the 'overlapping consensus', and wrote about 'reasonable pluralism' ${ }^{34}$ Enormous consequences flow from such basic realisations, which remain incompletely reflected in how law is taught or practised in most countries, including Bangladesh. The intensive connections of theory and practice with regard to recognising social normativities require further analysis, also in terms of the conflicts caused. Conflicts, too, are ubiquitous and exist in numerous manifestations. Initially, as holistic perspectives suggest, conflicts may be analysed as doubts in an individual's mind about which option or path to choose. While this is not normally included in legal analysis, it may be prudent to accept that legal psychology informs socio-legal enquiries. Thus, it seems not just advisable, but appears essential to consider individual agency in socio-legal analysis.

For this interdisciplinary task, the kite of law with its four competing corners, none of which may be ignored and rendered voiceless without risking a backlash of resentful violence, has by now proved its crucial relevance. It is not just a metaphor, but a heuristic tool that inspires action in a spirit of connectedness and compromise, rather than trying to score victory over others. ${ }^{35}$ The doubts of the individual law-related actor as an interconnected legal agent are probably encompassed and located within or close to corner 1 of the kite, the individual sphere, focused on ethics, values and beliefs. Such challenges of the deeply dynamic nature of all law, identified in a fascinating new book on Islamic law by one of the best South Asian law teachers I ever encountered, through the metaphor of a flowing stream, ${ }^{36}$ must be faced everywhere in legal education these days. Yet such efforts to update, pluralise and sensitise legal education are still constantly undermined by complacent laziness and lack of activism among law teachers.

There is much more to this, though, than laxity or inefficiency in legal education. There appears to be a tendency among Muslims, quite akin to the concerns and fears among doctrinal lawyers about pluralist challenges to legal certainty,${ }^{37}$ to deny the scope and possibility of doubt in the human mind. For many Muslims, this element of doubt seems to risk insecurity of belief, which is feared in a global context dominated today by secular predilections and principles. In the lived experience of Muslims, though, the realisation of one's agency as an individual believer, as someone who is expected to reaffirm that belief constantly through prayer, signifies a latent position, something that is 'in-between' the human sphere and the universe. As a thought process,

33 Roger Cotterrell, 'Still Afraid of Legal Pluralism? Encountering Santi Romano. Review Symposium: Law and Society Meets Jurisprudence' [2020 (45.2)] Law \& Social Enquiry 539, 553.

34 John Rawls, Political Liberalism (Columbia University Press 1993) 144-172.

${ }^{35}$ Werner Menski, 'Introduction: Conflicts over Justice and Hybrid Social Actors as Legal Agents' In Kyriaki Topidi (ed.) Normative Pluralism and Human Rights: Social Normativities in Conflict (Routledge 2018) 1-36.

37 Roger Cotterrell, 'Still Afraid of Legal Pluralism? Encountering Santi Romano. Review Symposium: Law and Society Meets Jurisprudence’ (2020) 45(2) Law \& Social Enquiry 539, 553. 
conceivable also in a spatial sense, this is a necessarily hybrid, plural status. Identifying exactly this predicament, a recent sophisticated study on the modern challenges to Islamic law presents a discussion of the subtle concept of dihliz, the threshold, a metaphor of in-betweenness that signifies the status of being connected, through consciousness, belief and appropriate action. ${ }^{38}$ This also represents the moment of decision-making or, putting it differently, the constant challenge of having to make decisions of all kinds, at any moment of our lives.

In more traditional legal scholarship on Islamic law, a more doctrinal position has been taken about this specific crucial element of decision-making. For example, we read first that 'Islam means total submission and surrender to Allāh', but then also find that 'while law in Islam may be God-given, it is man who must apply the law. God proposes: man disposes' ${ }^{39}$ Notably thus, plurality-sensitive analyses of how Muslims balance their submission to the divine will and individual agency tend to be presented in traditional literature on Islamic law as an exercise of jurisprudential skills and discretion. This obviously plays down the role and agency of the individual believer.

Yet, also in this jurist-focused context, scholarly writing cannot really avoid or bypass discussion of Islamic notions of plurality, found in the juristic technique of ikhtilaf ('unity in diversity'), which is supported by a well-known hadith to the effect that difference among Muslims is 'a sign of the bounty of God' ${ }^{40}$ However, in the highly plural practice of Islam as a way of life, the reduction of decision-making to jurisprudential analysis avoids addressing the intensely private and individual dimensions and predicaments for the Muslim believer. At that individual level, Muslims are fully justified to claim a context-specific right to live as Muslims, manifested in quite different actual practices among Muslims between the Balkans and Bengal. ${ }^{41}$ However, the more critical private as well as public challenge, also in Bangladesh, is (i) the extent of toleration for the presence of non-Muslims, (ii) the extent of acceptance of diversity among Muslims and (iii) and very important in lived experience, the degree of discretion allowed to individuals by other individuals. With regard to the first and second challenges, whether Muslims are a demographic minority or a majority should not make a difference in their approach to any 'others', leading us back to the already stated position that '[a] good Muslim is, therefore, of necessity, a pluralist' ${ }^{42}$ In a more recent formulation of this pluralist scenario, the conclusion is therefore obvious: ${ }^{43}$

Even to the casual observer of Islamic law, then, it should be clear that the manner in which law is generated within the Islamic legal traditions is most definitely pluralist, with the inherent capacity for alternative legitimate conceptions of what constitutes law and permissible action.

38 Shaheen Sardar Ali, Modern Challenges to Islamic Law (Cambridge University Press 2016) 1-3.

39 Noel J. Coulson, Conflicts and Tensions in Islamic Jurisprudence (University of Chicago Press 1969) 1.

40 Shaheen Sardar Ali, Modern Challenges to Islamic Law (Cambridge University Press 2016) 25.

${ }^{41}$ Shahab Ahmed, What is Islam? The Importance of Being Islamic (Princeton University Press 2016).

42 Werner Menski, Comparative Law in a Global Context. The Legal Systems of Asia and Africa (2nd edn, Cambridge University Press 2006) 281.

43 Shaheen Sardar Ali, Modern Challenges to Islamic Law (Cambridge University Press 2016) 26.

Page $\mid 8$ 
The challenge for Bangladesh as a Muslim majority nation is thus also quite clear. But the above analysis must also account for the all-too-frequent phenomenon of selfrighteously seeking to dictate to others, whether fellow Muslims or non-Muslims, how they should lead their lives and make decisions. Though this predicament and the related conflicts and tensions fall squarely within the private sphere, at first sight, when violence arises because a 'good Muslim' objects to what others are doing, we are only a few steps away from the terrible aberrations of blasphemy laws, which have been causing such havoc in Pakistani law. ${ }^{44}$ Significantly, there have been strenuous efforts to push for the introduction of such laws in Bangladesh in 2013 and thereafter. ${ }^{45}$

It is painful to remind Bangladeshis that the ferocity of violence during the War of Independence in 1971 was evidently more or less directly linked to such terrible mental struggles over self-righteousness, affecting the minds and actions of perpetrators. If this was not difficult enough, unfortunately we know in 2020/21 that proper balancing of such competing expectations about right belief and right conduct remain aggravated and partly overshadowed by petty partisan politics and by multiple further interventions in the kite journey of Bangladesh on the part of those who neither wish to accept socio-legal pluralism nor any form of religious diversity.

In the law classrooms of the global law school at SOAS, which were over time increasingly dominated by Muslim students from all over the world, including many local and overseas Bangladeshis, such issues had to be debated and clarified upfront, an essential part of the global comparative law education that students had enrolled for, explicitly related to the basic definition of law. ${ }^{46}$ Raising such issues in classroom debates required courage and respect for otherness, as it at once raised the question to what extent Islamic law was 'law'. This essential process of educating lawyers in the twenty-first century cannot be focused only on secular human rights protection, while treating religion as something extra-legal. I am well aware that such discussions in South Asian law classrooms may elicit protests by those who do not want students to think for themselves and acquire a holistic education. Opposition to creating educated law students who function as emotionally intelligent human beings rather than legal automatons is still supported, despite frequent assertions to the contrary, by the convenient view among doctrinal law teachers that state-centric law teaching is more important than all this 'fuzzy' talk about legal pluralism. It is significant that even in 2020, scholars who argue for and practise legal pluralist education have to defend such approaches against reductionist politicised law-centric scholarship. ${ }^{47}$

44 The best analysis on this, in my view, is a massive intercultural study of the relevant criminal law, written in German, but with a detailed bibliography of pertinent sources, which are mostly in English (pp. 869-917). See Benedikt Naarmann, Der Schutz von Religionen und Religionsgemeinschaften in Deutschland, England, Indian und Pakistan (Mohr Siebeck 2015).

45 Md Maidul Islam, 'Secularism in Bangladesh: an Unfinished Revolution' (2018) 38(1) South Asia Research 20, 28-29.

46 Werner Menski, Comparative Law in a Global Context. The Legal Systems of Asia and Africa (2nd edn, Cambridge University Press 2006) 173-190.

47 Werner Menski, 'On Kites and Ships: Climate Changes in Comparative Law and Judicial Navigation' in Seán Patrick Donlan and Jane Mair (eds.) Comparative Law. Mixes, Movements, and Metaphors (Routledge 2020) 67, 68. 
Not just in Bangladesh, rigid application of such law-centric ideologies and strategies does not help to create the best possible lawyers. Probably even more dangerously, though, too narrow instrumentalist legal education generates and endorses a selfcentred fascination with one's own powers, derived from believed-in supreme powers of 'the law', in complete opposition to what is now called 'social science legal pluralism' ${ }^{48}$ Remarkably akin to the deliberate silences in Islamic jurisprudence about the agency of the individual, this empowers those who claim knowledge of the "official law', which of course is never the only law, to impose their will on others, in classic stereotypical Austinian style. This malign development is rather unhealthily cultivated among politicians all over the world. Presently in the UK, the crashing kites of BREXIT at the start of 2021 indicate a disastrous path to self-harm through irresponsible leadership. In the USA, utterly undemocratic efforts by a sitting President to challenge an election that he lost, following hundreds of years of democratic practice, tell us that democracy remains potentially at risk everywhere, not just in South Asia.

\section{SYNERGIES OF PRIVATE AND PUBLIC INTEREST AND THE NEED TO PROMOTE A SUSTAINABLE FUTURE EVEN IN POST- COVID BANGLADESH}

Notwithstanding reservations about the abuse of political power by leaders who often studied law earlier in life, it remains a fact that somebody has to bear the responsibility of holding the strings of the nation's kite of law. In Bangladesh, that privileged stakeholder may at times appear confused over whether this function is a pious obligation and an onerous duty, or a privilege that may be exploited. One often wonders whether Bangladeshi leaders really think they could just govern like kings or queens in less democratic times.

Law-related teaching about leadership, which is part of my academic portfolio, suggests criteria for what makes a good leader. I was fascinated to hear in that context, when interviewing prospective students and asking about applicants' views on who is their role model as a leader, that the Prophet Mohammad came up very often. In fact, before receiving such responses, I had studied and discussed the key role of the Prophet in the early development of Islamic law. ${ }^{49}$ As leader, judge and guide of the emerging community of Muslims, the dihliz of the Prophet, to use the metaphor employed by Professor Shaheen Sardar Ali, ${ }^{50}$ was clearly completely unique. In fact, it is a wellknown part of Islamic doctrine that nobody is allowed to claim that same position ever again. Quite rightly so, for the dihliz of any other claimant to prophethood could indeed never be the same.

I raise this here, and in this way, because the highly contested politics and legal

48 Roger Cotterrell, 'Still Afraid of Legal Pluralism? Encountering Santi Romano. Review Symposium: Law and Society Meets Jurisprudence' (2020) 45(2) Law \& Social Enquiry 539, 547.

49 Werner Menski, Comparative Law in a Global Context. The Legal Systems of Asia and Africa (2nd edn, Cambridge University Press 2006) 294-298.

50 Shaheen Sardar Ali, Modern Challenges to Islamic Law (Cambridge University Press 2016) 1-3.

Page $\mid 10$ 
structures of Bangladesh are partly so aggressively handled that evidently it has not sunk in, fully enough, that nobody could ever be the same as the Prophet in his times. This is deliberately misused, it appears, as the challenges of governance and of operating the legal system in the Muslim-dominated nation of Bangladesh should by now have reached a state of maturity, where petty politicking to serve inflated egos and private interests is replaced by a supervening focus on the public interest of the entire nation. Instead, the unhealthily dualistic exaggerated claims to power, mixed with religious argumentations, continue to cause havoc.

In that context, reliance on Islamic arguments is not going to serve as a kind of cultural defence for those who argue that Bangladesh is a Muslim majority country and thus must put Islam in pole position. In the Covid-ravaged Bangladesh of 2020, it ought to be taken for granted that the majoritarian position of Islam and thus of Muslims in Bangladesh is simply a demographic and cultural fact, and there is an urgent need to move on from such old, tired conflicts. Constructive action to make the iccher ghuri of Bangladesh fly well must ensue, no longer held back by religious politics. The nation's legal system and rule of law may be fine-tuned in accordance with that realisation of a particular majoritarian demographic, with its evident mirror image in Hindu-dominated India, where similarly agitated debates rage over the role of Hindu identity and its relation to the nation state. In both countries, minority rights must not just be guaranteed on paper, but also in daily practice. As both major political parties in Bangladesh are run by Muslims, it is entirely disingenuous to claim that one of these parties seeks to damage Islam as the state religion of Bangladesh, while the other party protects it. Yet this also means that those who claim that acknowledging the pole position of a majoritarian religion in a plural nation is an infringement of international norms are wrong. First of all, religious demographics are a matter of fact. Secondly, there is no binding international norm decreeing that law and religion must be separated. The separatist approach is simply one possible theoretical option, which does not even work well in practice in the country that pushes for it most actively, France. If in today's postmodern conditions, where religion has 'come back' rather than receding into irrelevance, everything is to be treated as diversely connected, the politics of law and religion in Bangladesh are merely a devious device to stir up trouble, prevent sustainable progress, and trick the people into believing that one particular party is damaging the best interests of Islam. After all, as we know quite well from the misuses of blasphemy laws, discussed above, it is really simple to mislead 'normal' peaceful Muslims, because the rhetoric of present-day Islamic militants has somehow become 'music to the ears of pious Muslims' ${ }^{51}$ Cries of 'Islam in danger', however, seek to hide the fact that the law-related business of governance is multi-dimensional, extending far beyond 'law and religion'.

In this context, the four basic pillars of the national vision of Bangladesh remain the conceptual framework within which any discussion of the country's future development needs to be conducted. In 2015, I discussed this as the challenge of

51 Naseer Dashti, 'Is there a Non-Radical Islam?' in Richard L. Benkin (ed.) What Is Moderate Islam? (Lexington Books 2017) 73, 93. 
learning to live together, ${ }^{52}$ arguing that failure to manage this process risked crashing the wish kite of Bangladesh. I also suggested that the four elements of this national vision broadly match the four corners of the kite of law: Firstly, matching kite corner 4, nationalism as freedom from intervention by others, secondly democracy as full participation by all the people of Bangladesh as part of kite corner 3, thirdly secularism, reflecting the socio-religious and sectarian pluralities among the diverse people of the country and their values, thus matching corner 1 of the kite, and fourthly socialism, a basic principle which suggests that private interest and public interest have to be always, as much as possible, seen and operated together is social and economic domains, which match kite corner 2. This aspect of the vision also suggests that capitalist structures, which rely and insist on the freedom of contract, only empower a privileged elite, leaving common citizens completely behind, as various historical experiences of colonialism have shown. Whether postcolonial Bangladesh could lift itself out of such predicaments thus became a major litmus test of empowerment and development.

All four elements in this nation-building process of Bangladesh remain, in 2020, work in progress, not only due to continued basic disagreements over the country's visions, but more fundamentally, because the dihliz of Bangladesh, of course, keeps changing all the time, posing new challenges of appropriate decision-making, including the finetuning of the national identity. If legal scholars need any more proof that law is everywhere situation-specific, Bangladesh offers abundant evidence to verify this axiom. Regarding nationalism, which in the 1970s was a big emotional issue given the then recent divorce from Pakistan, today the struggle is much more whether to align more closely to India or to China, in various respects, ${ }^{53}$ while retaining national sovereignty and control over the nation, its assets and its borders. Significant progress has been made regarding earlier border disputes with India, especially the exchange of numerous enclaves. ${ }^{54}$ Compared to prominent earlier litigation challenging such steps,${ }^{55}$ the present position reflects a remarkable maturity, combined with realism on both sides about clearing up such messy borders left by colonial haphazardness. Challenges remain for keeping the nation as free as possible from international intervention. Yet as a country which became recently heavily dependent on exports of ready-made garments to bolster economic progress ${ }^{56}$ Bangladesh must also accept international laws and agreements in order to conduct such trade. It is too early to speculate what far-reaching implications the crashing export market for Bangladeshi garments will bring with it. Since the big neighbours, both India and China, are also suffering similarly disastrous economic consequences, it remains to be seen how

52 Werner Menski, 'Bangladesh in 2015: Challenges of the Iccher Ghuri for Learning to Live Together' (2015) 1(1) Journal of Law and Politics, University of Asia-Pacific, Dhaka 9-32.

53 Pravakar Sahoo, 'Economic Relations with Bangladesh: China's Ascent and India's Decline' (2013) 33(2) South Asia Research 123-139.

54 Amit Ranjan, India-Bangladesh Border Disputes. History and Post-LBA Dynamics (Springer 2018).

55 Naim Ahmed, Public Interest Litigation. Constitutional Issues and Remedies (Bangladesh Legal Aid and Services Trust (BLAST 1999) 21-22.

56 Mohammad Rafiqul Islam, 'Economic Growth Rates and Exports of Bangladesh: The Bengal Tiger?' (2019) 39(3) South Asia Research 285-303.

Page $\mid 12$ 
strongly certain patterns of regional and international solidarity are going to impact on bilateral and multilateral relations. Kite corner 4, the international recognition of Bangladesh as a nation, is by now a soundly secured component of the iccher ghuri, but faces risks from ongoing precarities that are affecting the other kite corners and components of the national vision.

Democracy as a core concept of a modern nation state concerns mainly corner 3 of the kite of law, but pertinent elements of this vision are also woven into the other three corners. A prominent example is the contested place of different religions in the pluralist legal order of Bangladesh, in view of Article 2A of the Constitution and its interaction with the provisions of Parts II and III. If by 2015 historical lessons had not been learnt about how to operate a functioning plurality-sensitive democratic system, ${ }^{57}$ in 2020 it is not possible to be entirely optimistic, either. It remains true to restate the view of a major observer of Bangladeshi developments, to the effect that '[d]emocratic governance has proved to be a particularly difficult project for the leadership'. ${ }^{58}$ Finding the right balances in governance structures at various levels, including management of democratic elections is a huge task. It seems fair to say that in the current adversarial political climate, the credibility and soundness of democratic structures will remain a matter of concern. The casualties in this ongoing battle appear to be the common people and the public interest, as well as hopes for securing fully accountable governance structures, an independent judiciary, and a press that enjoys freedom of speech. In all of these sub-domains, significant bottlenecks of positive development appear to persist. Additionally, the country now faces urgent emergencies regarding public health and the economy-related aspects of the national vision. Whether this massive set of challenges will generate new cross-party solidarities in a spirit of protecting the public interest can only be hoped for.

On secularism, much has been said above, and this remains a bone of contention, with no end in sight of aggressive posturing by various stakeholders, with the state struggling to respond. ${ }^{59}$ Continuous population movement from Bangladesh to India remains a concern. ${ }^{60}$ On socialism, which the kite model connects to corner 2 as a socio-economic aspect, while Bangladesh was beginning to do really well economically, ${ }^{61}$ multiple COVID-19 impacts are presently spelling disaster for the many positive achievements of the past few years. These involved significant female empowerment through high female labour force participation in this really hardworking nation. Those gains will now be lost to a very large extent, as it is likely that a major reorganisation of export policies will be necessary. Maybe this will provide

57 Werner Menski, 'Bangladesh in 2015: Challenges of the Iccher Ghuri for Learning to Live Together' (2015) 1(1) Journal of Law and Politics, University of Asia-Pacific, Dhaka 9, 23.

58 Rounaq Jahan (ed.) Bangladesh. Promise and Performance (Zed Books and University Press Limited 2000) 27.

59 Matthew J. Nelson and Seth Oldmixon, Bangladesh on the Brink: Mapping the Evolving Social Geography of Political Violence (Resolve Network, US Institute of Peace 2017) 7.

60 Amit Ranjan, India-Bangladesh Border Disputes. History and Post-LBA Dynamics (Springer 2018), 90-110.

61 Mohammad Rafiqul Islam, 'Economic Growth Rates and Exports of Bangladesh: The Bengal Tiger?' [2019, 39.3] South Asia Research 285-303. 
some positive impacts for more export-oriented aquaculture and seafood processing. But overall, it is difficult to be hopeful that the highly asymmetric social structures of Bangladeshi society, with their many disadvantaged sub-sections, ${ }^{62}$ will be able to avoid further suffering rather than partaking on equitable terms in the joyful making of butter.

\section{CONCLUSIONS}

The vision of a golden Bangladesh, this article suggests, remains meaningful and alive, but has also stayed largely unfulfilled. 20 years ago, Rounaq Jahan summed this up in words which are still reflected in current observations: ${ }^{63}$

Implicit in the idea of sonar Bangla was the vision of a society economically prosperous, free of exploitation, democratically governed, tolerant of pluralism, and respectful of people's rights. This vision mobilized the nation behind the liberation war and is still alive in the minds of average citizens as evidenced by people's movements for democracy and human rights and their initiatives for economic well being.

My own conclusions in 2015 observed that while managing the diversity of Bangladesh will never be easy, 'the key challenge for legal professionals, law teachers and their students, the present and future legal actors of this country', ${ }^{64}$ would be to understand that times are changing and there are new expectations that need addressing for protecting the nation and its ideals. Rounaq Jahan's analysis of the performance of Bangladesh proceeded with a detailed critique of the many shortcomings in governance in particular, ${ }^{65}$ but ended by expressing hope that the activism of new actors would add some shine to sonar Bangla. While my observations focused on diversity management and the role of lawyers, who clearly play a central role in Bangladesh ${ }^{66}$ Jahan's main hope rested on the increasing role of women as 'new actors in Bangladesh polity'. ${ }^{67}$ However, despite considerable achievements made by such new agents of change, ${ }^{68}$ the iccher ghuri of Bangladesh, in greatly uncertain times, continues to experience frightful turbulences on its path through the skies over Bangladesh.

Overall, any analysis of Bangladeshi developments from a particular perspective is

62 Mohammad Hamiduzzaman, Anita de Bellis, Wendy Abigail and Evdokia Kalatzidis, 'Elderly Women in Rural Bangladesh: Healthcare Access and Ageing Trends' [2018 (38.2)] South Asia Research 113-129.

63 Rounaq Jahan (ed.) Bangladesh. Promise and Performance (Zed Books and University Press Limited 2000) 26.

64 Werner Menski, 'Bangladesh in 2015: Challenges of the Iccher Ghuri for Learning to Live Together' [2015, 1(1)] Journal of Law and Politics, University of Asia-Pacific, Dacca 9, 30.

65 Rounaq Jahan (ed.) Bangladesh. Promise and Performance (Zed Books and University Press Limited 2000) 26-30.

66 Sonia Z. Khan, The Politics and Law of Democratic Transition: Caretaker Government in Bangladesh (Routledge 2018).

67 Rounaq Jahan (ed.) Bangladesh. Promise and Performance (Zed Books and University Press Limited 2000) 30.

68 Fardaus Ara and Jeremy Northcote, 'Women's Participation in Bangladesh Politics, the Gender Wall and Quotas', [2020 (40.2)] South Asia Research 266-281.

Page $\mid 14$ 
bound to come up only with particular aspects or nuances in suggested recommendations for improvements. Taking inspiration again from the dynamic threshold metaphor of the dihliz, it is absolutely clear now that many new challenging moments will continue to arise in and for Bangladesh, the current COVID-19 repercussions being a particularly brutal example. We can forever talk and lecture about sustainability, but when such disasters arise, there will probably be much chaos. Apart from that, inspiration may be drawn from old concepts like the Rawlsian 'overlapping consensus' and new writing on legal pluralist approaches that pays more attention to local justice in South Asia, ${ }^{69}$ closely related to what has been labelled as 'genuine legal pluralism', which of course needs coordination. ${ }^{70}$

As current evidence from Bangladesh confirms, it remains tempting and easy to criticise and advise, but terribly difficult to coordinate a sustainable path for the iccher ghuri of sonar Bangla. As a key component of governance, law remains subject to the never-ending dynamisms and challenges identified in this article. My hope is, above all, that the Faculty of Law of the University of Dhaka and the many other law faculties in the country, recognising the public interest element of the need for constructive coordination rather than adversarial games, will train and empower the next generations of lawyers to work assiduously for the inclusive sustainable development of genuine pluralism in Bangladesh. Let the kites of Bangladesh fly high!

69 Tobias Berger, Global Norms and Local Courts. Translating 'the Rule of Law' in Bangladesh (Oxford University Press 2017); Kalindi Kokal, State Law, Dispute Processing, and Legal Pluralism. Unspoken Dialogues from Rural India (Routledge 2020).

70 Roger Cotterrell, 'Still Afraid of Legal Pluralism? Encountering Santi Romano. Review Symposium: Law and Society Meets Jurisprudence’ [2020 (45.2)] Law \& Social Enquiry 539, 554. 
The Banglar Ghuri as a Metaphor for Inclusive Sustainable Development

Page | 16 